\title{
LA PUBLICIDAD DE LAS TIENDAS POR DEPARTAMENTOS DE LA CIUDAD DE MÉXICO EN LOS ALBORES DEL SIGLO XX
}

\author{
Cristina Sánchez Parra \\ Universidad Nacional Autónoma de México
}

G 1986 Peter Gay aludía al término manger (comer) en Cla obra de Émile Zola, El paraíso de las damas, ${ }^{1}$ como un sinónimo de séduire (seducir) para referirse al ambiente donde se desarrollaba su historia: una tienda por departamentos. Al respecto, mencionaba Gay: "los competidores se devoran entre sí con sus ofertas, las jóvenes vendedoras establecidas devoran a las recién contratadas con sus persecuciones, las tiendas de departamentos devoran a las tiendas antiguas de la capital, los clientes devoran la mercancía con los ojos; [al fin] son todos apetitos". ${ }^{2}$ Estos apetitos, en el sentido al que alude el autor, también pueden enmarcar el contexto de la consolidación de los grandes almacenes en la capital mexicana.

Los grands magasins, para utilizar la acepción francesa, señalan el contexto en donde nació la idea de construir un espacio que respondiera a las necesidades del consumo moderno,

Fecha de recepción: 15 de noviembre de 2018 Fecha de aceptación: 22 de julio de 2019

${ }^{1}$ El título original de la obra es Zola, Au Bonheur des dames.

${ }^{2}$ GAY, La experiencia burguesa, p. 300. 
amplio, higiénico y sobre todo donde pudiera encontrarse una variedad de mercancías, organizadas y clasificadas por secciones o departamentos. Estos se convirtieron en el paradigma que los inmigrantes barcelonnettes retomaron para consolidarse en el negocio de la venta de ropa y novedades. ${ }^{3}$ La primera tienda departamental inaugurada como tal en la Ciudad de México fue El Palacio de Hierro, un proyecto liderado por Joseph Tron quien, "a la manera de París”, 4 se inspiró en "Au Bon Marché, una tienda de enormes proporciones que en 1852 constituyó un gran edificio e instauró un nuevo sistema de comercio, la tienda departamental". 5

La innovación arquitectónica que representó la paulatina aparición de tiendas departamentales en la capital mexicana era una muestra del espíritu de la modernidad que se acompañaba con la racionalización de las ventas. David Bunker asegura que "sin duda, algún departamento era más grande que otro, pero el punto es que las tiendas estaban organizando, categorizando y separando los bienes, lo que mostraba tanto la abundancia de la sociedad moderna como la tendencia a la cuantificación y categorización”. ${ }^{6}$ De esta manera, los grandes

3 Algunas de las tiendas departamentales que surgieron en la época habían nacido como cajones de ropa, que eran pequeños almacenes de venta de textiles, que guardaban las mercancías en armarios amplios, los cuales mantenían fuera del alcance de los compradores, quienes estaban obligados a solicitar al dependiente el género de su preferencia y luego, regatear el precio del mismo. La estrechez del espacio y la forma de hacer la transacción contrastará posteriormente con la propuesta de las tiendas departamentales. Véase BÈrAUDSuberville, "Centinelas del pasado", pp. 247-280.

${ }^{4}$ Los grandes almacenes aparecieron en París a mediados del siglo xIx y rápidamente se expandieron por otras ciudades a lo largo del siglo y a principios del siglo xx. La historia del primer grand magasin en París se encuentra en Miller, $A u$ Bon Marché. Mientras que un análisis del impacto económico y social de otra gran tienda parisina: La Belle Jardinière, fue realizado por FARAUt, Histoire de la Belle Jardinière.

${ }^{5}$ Martínez, El Palacio de Hierro, p. 41.

${ }^{6}$ Bunker, Creating, p. 145. 
almacenes o tiendas departamentales ${ }^{7}$ marcaron una ruptura en el rumbo del comercio de telas, ropa, accesorios y novedades de la Ciudad de México, donde para entonces predominaban los cajones de ropa y los almacenes especializados, como camiserías, sederías o tiendas de rebozos.

Por supuesto, la aparición y consolidación de las tiendas departamentales, desde la última década del siglo xix y hasta inicios del xx, no significó la desaparición de los comercios tradicionales sino que al contrario, enriquecieron el paisaje comercial urbano, el cual se dirigía a determinados sectores sociales. Desde el comienzo, los grandes almacenes se enfocaron en las capas altas de la sociedad y en algunos sectores de la clase media mexicana. Para la época que nos atañe encontramos la existencia de más de una decena de grandes tiendas, a saber: El Palacio de Hierro, El Surtidor, La Francia Marítima, La Reforma del Comercio, Las Fábricas Universales, Al Progreso Mercantil, El Puerto de Veracruz, Al Puerto de Liverpool, La Ciudad de Londres, La Bella Jardinera, El Centro Mercantil, Sorpresa y Primavera Unidas, La Nueva Bella Jardinera y Las Fábricas de Francia. ${ }^{8}$

La existencia de estas tiendas fue posible gracias a unas condiciones económicas y políticas que no sólo incentivaron la inversión extranjera sino que a la vez que promovieron las importaciones dieron un espaldarazo a la industria nacional. En este complejo panorama económico se insertaron los grandes

\footnotetext{
7 Es importante señalar que en las fuentes revisadas los términos se utilizan indistintamente, aunque en ocasiones se encontró la referencia a "gran almacén" para hacer énfasis en la respetabilidad del comercio o la calidad de los productos que vendía sin que esto implicara necesariamente que la casa estuviera dividida por departamentos.

${ }^{8}$ Los nombres se identificaron a partir de la revisión de prensa realizada y en un manuscrito titulado Principales maisons du commerce Françoise au Mexique, que data de 1900 en ARFM, Raíces Francesas en México, Archivo sin clasificar. Un estudio sobre el impacto de las tiendas departamentales en el consumo de los habitantes de la capital mexicana se encuentra en SÁNcheZ Parra, "Novedad y tradición", p. 43.
} 
almacenes, cuyos representantes conformaban la "crema y nata" francesa en la capital mexicana. Como lo señala Aurora Gómez-Galvarriato, a partir de la segunda mitad del siglo XIX, en Estados Unidos y Europa occidental, las nuevas formas de comunicación y transporte transformaron la manera en que se distribuyeron los productos manufacturados. Para el caso mexicano, la construcción de nuevos caminos ferroviarios, así como la ampliación de las líneas telegráficas, influyeron en el ritmo de los negocios del país. De esta manera, al tiempo que el progreso se manifestaba, por medio de la existencia de los grandes almacenes, se dio fuerza a la industria nacional. ${ }^{9}$

Debido a estas condiciones, las tiendas departamentales se consolidaron en la capital mexicana como comercios minoristas con la fórmula de "vender mucho a bajo costo" y, paulatinamente, fueron haciendo presencia en el resto del país gracias a la venta al mayoreo, que les permitió distribuir sus mercancías en las tiendas de otros estados al principio y luego, construyendo sus propios almacenes, esto particularmente en las principales capitales, como Guadalajara y Tampico. Vemos así que la idea de la modernidad iba de la mano con la existencia de estas casas comerciales. Al respecto asevera Patricia Martínez:

La idea de este prototipo de comercio se asoció con el de modernidad en el aspecto urbano y arquitectónico, por la vanguardia de sus edificios; en lo social, porque por primera vez la mujer salía a la calles sola para una actividad no religiosa, y en lo comercial, por la diversidad de artículos y de novedades que en ellos se podían

\footnotetext{
9 En el despunte del siglo xx, muchos de los socios de las tiendas por departamentos también se convirtieron en dueños de grandes industrias textileras en México. Por ejemplo, los socios del Palacio de Hierro eran los mayores inversores de la Compañía Industrial de Orizaba S. A. (cidosa). Por su parte, la sociedad que conformaba la dirección de Las Fábricas Universales tenía participación mayoritaria en la Compañía Industrial Veracruzana S. A. (CIVsA). Véase Gómez-GalvarRiato, Industry and revolution.
} 
obtener (desde armónicas hasta herramientas, pasando por telas, vestidos, muebles y cristalería). ${ }^{10}$

Hablando propiamente de la distribución de los espacios del edificio comercial, por lo general, estaban compuestos por más de dos plantas, dedicados a la venta al menudeo en los pisos más bajos y a la venta al por mayor, en los altos, desde donde se distribuía la mercancía al resto del país, consolidando la presencia de los productos importados por estas casas comerciales. Por supuesto, la distribución de los espacios fue cambiando a medida que las tiendas fueron creciendo y consolidando su identidad como tiendas por departamentos. Por ejemplo, François Arnaud describe que para mediados del siglo xix los cajones de ropa tenían un mostrador largo y ancho que separaba las mercancías de los clientes y que estaban custodiados por los dependientes. En este mismo nivel, en la trastienda, se cerraban los negocios de la venta al por mayor. Esto cambió con la construcción de los grandes almacenes, los cuales, siguiendo el modelo parisino, utilizaban la planta baja y el primer piso para la venta minorista y los pisos altos para los negocios de mayoreo; las tiendas más grandes se reservaban el último piso para las habitaciones de los empleados. ${ }^{11}$

Se sumaba, a la presencia de estos edificios, la contratación de dependientes, mayoritariamente de origen francés, lo cual enmarcaba un campo de distinción afín al gusto galo, particularmente en lo competente a la actualización de la vestimenta, es

10 Martínez, El Palacio de Hierro, p. 16.

${ }_{11} \mathrm{Al}$ respecto pueden leerle las descripciones de las tiendas en El Mundo Ilustrado (18 sep. 1914), pp. 52-67; Arnaud, Charpenel, Martin y Signoret, Les Barcelonnettes, pp. 14-15. Además, un plano transversal de Las Fábricas Universales comprueba esta distribución espacial al mostrar que se realizaba la venta al menudeo en la planta baja y el primer piso, en los dos niveles siguientes se señala la venta al por mayor, más arriba se ubicaban los talleres y finalmente, en el último nivel, las habitaciones. Véase Homps-Brousse, L'aventure architecturale, p. 34. 
decir, la moda. Para finales del siglo xix, el gusto español había sido reemplazado por los imaginarios franceses sobre el buen gusto en el vestir, cuestión de vital importancia para una sociedad que, con la modernización de las instituciones, comenzaba a evidenciar cierta movilidad social. ${ }^{12}$ La experiencia del consumo se completaba con la expansión de la publicidad, que buscaba seducir y estimular la apetencia por las compras. El asunto publicitario es particularmente importante, pues permite relacionar la propagación de la imagen y el consumo con el proceso de modernización. Siguiendo a Julieta Ortiz Gaitán, "la irrupción de la modernidad industrial propició que las imágenes con fines comerciales invadieran espacios públicos tales como los muros de las ciudades y las páginas de los periódicos". ${ }^{13}$

Precisamente, este artículo busca exponer las diferentes estrategias publicitarias utilizadas por los grandes almacenes capitalinos, para captar la atención de su clientela y consolidarse en el escenario comercial de la época, gracias a la captación de muchos clientes asiduos a sus mercancías. ${ }^{14} \mathrm{Al}$ mismo tiempo, el recorrido por los diferentes medios publicitarios permitirá conocer aspectos sobre la Ciudad de México durante el cambio de siglo, por ejemplo, las concepciones de higiene y las normas aplicadas por el Ayuntamiento con el fin de poner a la capital mexicana al mismo nivel que las grandes ciudades del mundo, mismas que inspiraban estos proyectos.

12 A propósito de la vestimenta como signo de distinción véase Pérez MonRoY, "Modernidad y modas", pp. 51-80. Un estudio sobre la modernización de las instituciones y la movilidad social puede encontrarse en el trabajo de Barbosa, “Capacitación”, pp. 747-783.

13 OrTIz, Imágenes del deseo, p. 28.

${ }^{14}$ En este artículo me adhiero a la distinción terminológica que hace Antonio Pineda entre publicidad y propaganda; él señala que "la publicidad responde a la intención de las empresas comerciales de vender sus productos y servicios, o implantar sus marcas en la sociedad. Y es en ese terreno donde deben dilucidarse sus diferencias con las manifestaciones propagandísticas generadas por las instancias de poder [con fines ideológicos"], PINEDA, "Propaganda", p. 124. 
De esta manera, en el proceso enmarcado por la inminencia del arribo al siglo xx, las ciudades se modernizaban, para estar a tono con los vientos de cambio. Aprovechando el "espíritu de la modernidad" que invadía la capital mexicana, las tiendas departamentales se embarcaron en una empresa revolucionaria, consolidar el consumo de bienes suntuarios. Su éxito no radicó solamente en haber aprovechado la oportunidad del momento sino en construir un discurso publicitario ${ }^{15}$ coherente con la "pastoral moderna" que pretendía hacer de la vida un "gran desfile de modas, un sistema de apariencias deslumbrantes, fachadas brillantes, refulgentes triunfos de la decoración y el diseño". ${ }^{16}$

Frente a esto, los grandes almacenes de la capital mexicana, además de utilizar las páginas de la prensa o de pegar carteles en los muros de la ciudad, que eran estrategias publicitarias tradicionales,${ }^{17}$ transmitieron la necesidad de consumir mercancías que no se consideraban prioritarias para la subsistencia, más bien, eran productos que aludían al lujo, a la prestancia y a la diferenciación social. Este sentido del gasto ya había causado interés en economistas como Adam Smith, quien identificaba un consumo que buscaba la satisfacción de lujo y reconocimiento social por sobre la necesidad básica de consumir lo necesario para vivir:

15 Atiendo a la conceptualización que hace Sergio Valerio Ulloa sobre el "discurso publicitario" el cual, asegura el autor, tuvo dos propósitos: "la promoción y venta de sus productos, e impulsar la modernidad y la moda de fines del siglo XIX y principios del siglo Xx, cuyos modelos a imitar se situaron en Europa, específicamente en París", en Valerio Ulloa, “Discursos”, p. 300.

16 Berman, Todo lo sólido, p. 134.

17 Por ejemplo, para 1812, Julieta Pérez Monroy dice que se comenzaron a anunciar en los periódicos diversas ofertas que también fueron criticadas porque no siempre la calidad de los productos correspondía con lo anunciado. Pero había surgido la publicidad de la moda, Pérez Monroy, "Modernidad y modas", p. 60. 
La preferencia de Smith por los bienes duraderos es el resultado de la multiplicación de los nuevos bienes que tiene lugar durante el siglo xviII, la cual provoca un cambio respecto al gasto del consumo de servicios personales hacia los bienes duraderos, junto con el fortalecimiento del deseo de obtener los nuevos bienes presentes en el mercado tales como mobiliario, adornos, vestimenta, cerámicas, etc. ${ }^{18}$

El proceso de construcción de un nuevo lenguaje publicitario puede explicarse con Bernard de Mandeville, quien aseguraba que este fenómeno consistía en una modificación de la "idea mercantilista según la cual la adquisición de bienes de lujo era fuente de empobrecimiento para sostener que su consumo promovía la emulación y el deseo de superación, que despierta entre los hombres el orgullo por alcanzar un nivel de vida mejor”. ${ }^{19}$ Así, la existencia de estos comercios contribuyó con la modificación del sentido del consumo de los habitantes mexicanos, quienes valoraron como un acto de buen gusto el asistir a estos lugares para adquirir mercancías importadas relacionadas con la indumentaria, los accesorios del vestido y otros artículos que podían ostentarse y, por ende, proporcionaban cierto estatus social.

Parte importante de las estrategias de venta de estas tiendas reposaba en la decoración de sus espacios. Las vitrinas que daban hacia la calle comenzaron a dominar el paisaje urbano, atrayendo la mirada de los transeúntes que, aun sin intención de comprar, se detenían para apreciarlas. La decoración de los aparadores incluso fundó un nuevo oficio dentro del sistema de jerarquías de los empleados de las tiendas, el de escaparatista, dedicado exclusivamente a decorar las vitrinas externas e internas

${ }^{18}$ El tema es abordado ampliamente por Rosenberg, "Adam Smith, consumer tastes", pp. 361-374.

19 Carmagnani, Las islas del lujo, p. 240. 
de la tienda, utilizando para este fin las nuevas tecnologías que llegaban al país, como la luz eléctrica. De esta manera, los maniquíes se vestían con los exuberantes colores de las telas que se vendían, los sombreros, paraguas o bastones complementaban el ajuar, sin perder de vista el escenario que envolvía esta exhibición, que contaba una historia en sí misma. La decoración de los aparadores formó parte del lenguaje publicitario de los grandes almacenes; incluso en las páginas de la prensa podían encontrarse descripciones como la siguiente:

En un aparador de los que miran a la calle de la Palma, exhibimos hoy los siguientes vestidos, confeccionados en nuestros talleres:

UN VESTIDO DE NOVIA, vestido ideal, de charmant de seda, marfilino, sirviéndole de adorno ricos encajes realzados.

UN VESTIDO NEGRO, crepé seda muselina, caprichosamente adornado con abalorios y flecos.

UN VESTIDO DE ENCAJE, rico encaje valenciano, al que dan singular atractivo bandas de satín color salmón.

UN VESTIDO ROSA, de muselina de chiffon, con aplicaciones de plata, que le prestan gran encanto.

UN VESTIDO AZUL, de muselina chiffon, guarnecido con encajes de chantilly, el tono es un delicado azul celeste $\left[\ldots . . .^{20}\right.$

Además de enviar un claro mensaje publicitario, este anuncio, que pertenecía al almacén denominado La Ciudad de Londres, propiedad de Joseph Ollivier, representaba uno de los preceptos del comercio moderno que llegaba desde Europa, el de la exposición permanente. Es decir, la exhibición continua de las mercancías que estaban a la venta. Hasta antes de la aparición de los grandes almacenes en México, era usual que las mercancías estuvieran almacenadas en armarios, resguardadas por los vendedores quienes, detrás del mostrador, marcaban una clara

20 Sin título, El Imparcial (5 jun. 1910). 
frontera entre los productos y los clientes. La compra entonces comprendía la solicitud al dependiente del género de tela de su interés o el objeto que se deseara, para apreciarlo más de cerca y siempre bajo la mirada vigilante del empleado, y, finalmente, aceptar o desistir de la transacción. No sorprende que ante la innovación que representaba la posibilidad de ver y tocar las mercancías, las tiendas departamentales causaran emoción entre sus visitantes; así lo describe un testigo de la época:

En su recorrido, el visitante podía ver la grandeza y elegancia del inmueble, a pesar del molesto mostrador de la planta baja; en los siguientes pisos, a los cuales se llegaba por una amplia escalera o por un elevador, se vendían artículos diversos en los múltiples departamentos del almacén, como el de telas y el de mercería, la sección de muebles finos que se elaboraban en los propios talleres del almacén, y el departamento de paraguas, tapices y otros objetos importados de París. El segundo piso se encontraba reservado a la confección y ropa para damas, todo aquello que en una palabra compone la pulcritud femenina $[\ldots] .^{21}$

Estos cambios en la actividad de las compras marcaron nuevas subjetividades sobre el consumo, imprimiendo cierto placer que se enmarcaba en el uso de la vista y el tacto para elegir los bienes. Así, la voluptuosidad de las mercancías exhibidas en las vitrinas y los pasillos de las tiendas conllevaba una experiencia placentera cuando esa mercancía por fin era poseída; al menos esa era la idea que se quería propagar entre los compradores. En palabras de Gay, las tiendas departamentales suscitaban una experiencia tan placentera como erótica: "la mercancía de los escaparates respira, emite un estremecimiento sugestivo; vibrando con calidez, insinúa y a la vez oculta los tesoros que hay dentro. En la tienda misma, la atmósfera es, si se puede, más acariciante, más

${ }^{21}$ Gouy, Pérégrinations, p. 60. 
seductora aún. En una pequeña alcoba en la que se exhiben encajes, los clientes entran con el rostro pálido, los ojos brillantes y un temblor apenas disimulados". 22

El concepto de exhibir de manera opulenta artículos o productos relacionados con un campo particular de la producción puede remontarse a la primera Exposición Universal, que tuvo lugar en 1851. Esta exposición, conocida como la Crystal Palace Exposition en Londres, ${ }^{23}$ marcó la hegemonía del capitalismo en ascenso, al mostrar los nuevos productos traídos de las colonias británicas y propagar la idea del "exotismo del consumo", misma noción que sería retomada por los socios de los grandes almacenes mexicanos para impulsar la venta de productos "importados de Europa”. Respecto a las exposiciones universales, dice María de Lourdes Herrera que éstas "alcanzaron un éxito notable en la difusión y promoción de ideas, comportamientos y avances técnicos. La voz estridente y mecánica del progreso resonó en el Crystal Palace y desde 1851 dejo oír su eco en los posteriores recintos que al efecto se habilitaron". ${ }^{24}$

En términos generales, las exposiciones universales representaron el progreso material de la sociedad; esta idea fue muy bien representada en el acto que se organizó en París en 1899. Para esa época, Francia encarnaba los ideales de la modernidad y, en consonancia, la élite porfiriana en México pretendía caminar en esa dirección: "si el objetivo era ser moderno, Francia era la Meca a la que había que peregrinar en 1899 ". ${ }^{25}$ De esta manera, la participación de México fue una estrategia para darse a conocer como

22 Gay, La experiencia burguesa, p. 298.

${ }^{23}$ La ciudad de París fue la continuadora de la tradición de las exposiciones universales: en 1855, 1867, 1878, 1889 y 1900; razón por la cual esta ciudad es considerada, por algunos historiadores, como "la cuna de la Revolución del Consumo". Al respecto véanse Williams, Dream Worlds, y Gurney, "The Sublime of the Bazaar", pp. 385-405.

${ }^{24}$ Herrera, "La puesta en escena”, pp. 25-26.

25 Tenorio, Artilugio, p. 36. 
sociedad civilizada y moderna y, a su vez, legitimar al gobierno en el ámbito internacional. Así, el certamen universal fue un gran escaparate que permitió mostrar los productos mexicanos, los avances técnicos y tecnológicos introducidos en la incipiente industria del país y, además, codearse con las naciones abanderadas del liberalismo económico.

Las exposiciones universales exaltaron dos elementos que constituirían la filosofía de los grandes almacenes: por un lado, retomando la expresión utilizada por Walter Benjamin, el “universo de las mercancías”, es decir, se resaltó el valor de los objetos en virtud del precepto de ser vistos para ser deseados y por ende querer adquirirlos. Este proceso, a su vez, fue marcando un camino de distinción entre aquellos que podían en efecto comprarlos y quienes sólo podía limitarse a observarlos, como en una galería. ${ }^{26}$ Por otro, el espectáculo de las mercancías se convirtió en la apoteosis del peregrinaje del paseante o flâneur que asistía a las tiendas. Los vistosos aparadores que, adornados, estimulaban la vista de los paseantes citadinos, fueron entonces una manifestación de esa experiencia moderna aprendida de los certámenes universales acontecidos, ni más ni menos, que en las principales ciudades del mundo.

A propósito del caso mexicano, menciona Denise Hellion que

[...] la construcción moderna recuperó las innovaciones presentadas desde la exposición universal de Londres, donde Joseph Paxton presentó su Palacio de Cristal. En él, el acero y el vidrio alteraron para siempre la concepción de los espacios interiores; la exhibición

26 Bourdieu menciona que "el gran almacén es la galería del pobre, no sólo porque ofrece objetos que forman parte del mundo familiar, de los que se conoce su uso [...] sino también, y sobre todo, porque en él no se siente uno medido con arreglo a normas trascendentes, es decir, con las reglas del savoir-vivre de una clase considerada como superior, y sí autorizado a juzgar libremente, en nombre de la legítima arbitrariedad de los gustos y colores". Bourdieu, La distinción, p. 32. 
podía disponer de dimensiones que no habían sido posibles sino hasta la segunda mitad del siglo XIX". ${ }^{27}$

Pero no sólo fueron las vitrinas las que cautivaron a los paseantes y posibles consumidores; la adecuación de los espacios interiores de los almacenes perfilaron una verdadera revolución del consumo, creando escenarios que abstraían a los visitantes de los espacios urbanos y los ubicaban en evocaciones de grandes y espaciosos salones dignos de ser caminados una y otra vez. En palabras de Benjamin, la relevancia de los espacios interiores como espacios creados para el disfrute de los ciudadanos consistía en que "el interior no sólo fue el universo del ciudadano común sino su envoltura. Vivir significa dejar huellas. En el interior se subrayaron estas huellas. Se inventaron en abundancia cubiertas y forros decorados, cajas y envolturas, moldeando las huellas de los objetos cotidianos" ${ }^{28}$

Las estanterías decoradas y la disposición de los espacios interiores fueron apenas dos de las expresiones de esta revolución del consumo, misma que se extendió por los espacios públicos de la capital. El escenario urbano se convirtió en una vitrina comercial que informaba desde las disposiciones legales del gobierno local hasta los espectáculos de circo, toros y teatro y, por supuesto, fue el espacio ideal donde las tiendas departamentales hicieron eco de su creatividad, por medio de los carteles. El affiche o cartel, como medio de comunicación, ocupó un lugar importante en la cotidianidad de la ciudad en plena transición de siglo. Al respecto, las reglamentaciones sobre la colocación de carteles en los muros de la ciudad se convierten en una fuente prolífica que permite seguirle la pista a la manera en que el ayuntamiento legisló sobre la ciudad y también ver el desarrollo creativo y tecnológico de estas propuestas publicitarias.

27 Hellion, Exposición permanente, p. 99.

28 Benjamin, París, p. 38. 
Las innovaciones comerciales ejercieron una fuerte atracción por el consumo, cambiando de esta manera los hábitos de los ciudadanos capitalinos. Según Hellion "el consumo se ritualiza, pasa de una acción a un proceso pautado por cambios dictados por los grandes almacenes que son aparadores de la imaginería". ${ }^{29}$ Uno de los objetivos de estas casas comerciales era consolidarse en el paisaje cotidiano de los habitantes de la ciudad, por lo que la conquista de las rutas de paso de los posibles compradores era más que estratégica, se hacía necesaria para su consolidación en la cultura urbana de la época. La conquista de las calles de la capital por la publicidad exigía de los transeúntes nuevas habilidades para recorrerlas, se caminaba, se observaba, se deseaba y, quizá, se compraba. ${ }^{30}$

\section{LA CIUDAD PARLANTE: LAS CALLES Y LOS ANUNCIOS}

\section{PUBLICITARIOS}

Para los habitantes de la Ciudad de México, recorrer sus calles podía significar el encuentro con varias realidades al mismo tiempo. Por un lado, no hay que perder de vista que era una urbe en plena ebullición, lo que se manifestaba en las frecuentes obras públicas, la ampliación o la apertura de calles e incluso de colonias que iban extendiendo la mancha urbana capitalina. A nivel cultural, también era el escenario de nuevos inventos, como el cinematógrafo que llegó de París y se inauguró en la ciudad mexicana en $1895 .{ }^{31}$ Por otro lado, el transeúnte también

\footnotetext{
29 Hellion, Exposición permanente, p. 103.

30 Berman señala que el individuo moderno se transforma en un arquetipo de nuevo peatón que es "lanzado" a la vorágine de la vida moderna, BERMAN, Todo lo sólido, p. 158.

31 Un panorama de esta situación cambiante lo brindan el Diario Oficial y las Memorias del Ayuntamiento. Ambas publicaciones fueron emitidas por el gobierno de la ciudad desde 1892.
} 
se encontraba con problemas higiénicos, ${ }^{32}$ dificultades de tránsito a raíz de la convivencia de los coches de tracción animal con los carros de motor, un fluido comercio informal y hasta la existencia de jaurías de perros callejeros que llegaron a amenazar la vida de los paseantes. ${ }^{33}$

Es justamente en este escenario contrastante donde se establecieron los carteles publicitarios que tapizaron los muros de las calles. No obstante, es necesario aclarar que la práctica de poner carteles visibles al público no era novedosa, basta recordar que "desde las gacetas novohispanas se anunciaba la venta de casas, anuncios de espectáculos, travesías marítimas, libros y avisos oficiales como los edictos del virrey". ${ }^{34}$ Sin embargo, para inicios del siglo xx el comercio de productos relacionados con la vestimenta y sus accesorios había crecido gracias a la consolidación de las tiendas departamentales. Esto generó no sólo que las casas comerciales quisieran tener presencia publicitaria en las principales calles, sino que se hizo más fuerte la idea de la competencia por la venta, por lo que también aumentaron los carteles de propaganda de diversas tiendas. A propósito, señala Ortiz:

[...] a los carteles adheridos en los muros, se añaden anuncios de gran formato pintados directamente en las paredes, lo que propició una variedad de dimensiones que contribuyó a la riqueza del paisaje urbano. Algunos anuncios obedecían a la costumbre de pintar las

32 En el Diario Oficial encontramos múltiples noticias relativas a la imperiosa necesidad de limpiar las calles como medida para evitar enfermedades. Véase, por ejemplo: "La higiene de las calles" (15 nov. 1904) o "El pueblo debe asearse” (15 oct. 1909).

33 A inicios del siglo xIX existía en la ciudad una "casa de utilización de despojos de animales" la cual se encargaba de controlar y recoger los animales muertos en la ciudad. Para 1902 un informe de esta casa señalaba entre sus actividades el levantamiento de 15322 perros envenenados en la vía pública. Véase "Matanza de perros”, en Diario Oficial (12 ago. 1902).

34 Ortiz, Imágenes del deseo, p. 34. 
fachadas con motivos alusivos a las actividades de los establecimientos comerciales $[\ldots]^{35}$

Por su parte, Emma Cosío de Villegas también identificó esta vocación propagandística de las calles de la ciudad; en una descripción señala que para el año de 1874 “se estrenaron en el Zócalo y en la Alameda unos elegantísimos quioscos de cristal para fijar anuncios y avisos, como los que existían en todas las grandes ciudades. Con el objeto de atraer gente a leer los anuncios se vendían en ellos dulces, refrescos, juguetes, periódicos y muchas otras chucherías". ${ }^{36}$ Podemos decir que, con el paso del tiempo, la práctica de anunciar en las calles por medio de carteles se incrementó, se diversificó e incorporó nuevas tecnologías. Los carteles eran hijos de su tiempo.

A finales del siglo xIx, era tan común la práctica de pegar carteles en los muros públicos que el Ayuntamiento de la ciudad de México se dio a la tarea de administrar y controlar la colocación de estos affiches. Una de las medidas tomadas en 1891 anunció el nombramiento de un inspector o "policía de letreros" cuyas funciones se especificaban de la siguiente manera: El policía de letreros debía:

[...] examinar todos los letreros públicos puestos a los establecimientos comerciales e industriales de la Ciudad y que forme un cuadro estadístico de ellos; que lleve un registro constante de los que se pongan a los que nuevamente se abran, que promueva en forma confidencial, si se quiere, la corrección de los errores existentes y vigile no se cometan en los letreros en lo sucesivo y por último, que dé cuenta cuando alguno falte a la moral u otra que exija medidas a fin de promover que la policía intervenga y las haga efectivas. ${ }^{37}$

35 Ortiz, Imágenes del deseo, p. 34.

36 Cosío, "La vida cotidiana”, p. 488.

37 AHDF, $P l$, exp. 62, Se nombra indefinidamente inspector de letreros públicos a Alberto Díaz Ruyama, vol. 3659 (16 de octubre de 1892). 
Este inspector además debía ser una persona "ilustrada y capaz de conocer bien no sólo el lenguaje español sino el francés que mucho se usa en algunos letreros y hasta algo de inglés". ${ }^{38}$ No es de extrañar que muchos avisos publicitarios se escribieran en francés; esto puede deberse a dos factores: por un lado, el hecho de que la mayoría de las tiendas por departamentos y negocios dedicados a la venda de ropa y accesorios eran propiedad de franceses provenientes de Barcelonnette. ${ }^{39}$ Por otro lado, el imaginario social construido en torno a lo francés como símbolo de distinción y buen gusto.

Volviendo a las funciones del inspector de letreros, los documentos del Ayuntamiento resaltan su importante labor de vigilancia, la cual contribuía al mejoramiento físico y cultural de las calles de la ciudad, pues como lo mencionaba la prensa, los carteles con mala ortografía, desgastados o feos a la vista, daban a los visitantes una idea de inferioridad y "a causa de ella se juzga de un modo inconveniente no sólo al pueblo sino también a las autoridades municipales". ${ }^{40}$ A pesar de la perentoria labor de los policías de letreros y de su invaluable contribución a la imagen de la ciudad ante sus ciudadanos y ante el mundo, por medio de la mirada de los visitantes extranjeros, el Ayuntamiento no se comprometió a pagar un salario a la persona que aceptara esta importante misión.

38 AHDF, $P l$, de letreros, exp. 62, Se nombra indefinidamente inspector de letreros públicos a Alberto Díaz Ruyama, vol. 3659 (16 de octubre de 1892).

39 A propósito de la migración de los barcelonnettes en México véase Pérez Siller (coord.), México-Francia; y Pérez Siller y Cramaussel (coords.), México-Francia, vol. II. En el campo particular de la influencia de los barcelonnettes en el comercio de la Ciudad de México es indispensable mencionar los trabajos de Gamboa, Los barcelonnettes; Salazar y Meyer (coords.), Los inmigrantes; Gómez-GaLVARRIATO, Industry E Revolution; "Industrialización” y Morales, "Los franceses en México”.

40 AHDF, $P l$, exp. 62, Se nombra indefinidamente inspector de letreros públicos a Alberto Díaz Ruyama, vol. 3659 (16 de octubre de 1892). 
El argumento expuesto por las autoridades se puso en el terreno moral, se arguyó que era una labor de digno compromiso ciudadano que debía cumplirse con orgullo y sin pretensiones financieras. A pesar de la imposibilidad de ser considerado un "empleo verdadero", algunas personas se ofrecieron como voluntarias. Como ejemplo se puede señalar el de un profesor de instrucción primaria con estudios filológicos quien se ofreció, sin quitar el puesto oficial al inspector de letreros, el señor Epifanio Rivera, para enviar informes mensuales de los letreros que él veía en los comercios de la ciudad. ${ }^{41}$ Es justo aclarar que ninguno de los dos percibió salario alguno, la única diferencia era el reconocimiento formal de don Epifanio como el policía de letreros de la ciudad.

Las diferentes reglamentaciones encontradas y que pretendían poner orden en la colocación indiscriminada de avisos publicitarios dan cuenta de la extensión de esta práctica comercial a lo largo de la ciudad. Para 1903, el cabildo designó como regla básica que "toda denominación de establecimiento que se abra al público tendrá su designación escrita en idioma español [...] si los propietarios desean hacer uso de un idioma extranjero, estarán obligados a poner la traducción respectiva en idioma español”. ${ }^{42}$ El Diario Oficial ratificó estas disposiciones mediante una legislación que buscaba defender el "derecho a la publicidad". Es decir, se planteaba una apuesta por la "democratización” del lenguaje publicitario en la ciudad, exigiendo que todos pudieran acceder al mensaje ya que "los letreros, anuncios, denominaciones de establecimientos mercantiles y fabriles que están escritos en otro idioma que el español, no aprovechan

41 AHDF, $P l$, exp. 63, Díaz Alberto pide permiso para el establecimiento de torres con anuncios comerciales, vol. 3659 (18 de noviembre de 1892).

42 AHDF, $P l$, exp. 146, Acuerdo para que toda denominación de establecimiento que se abra al público tenga su designación escrita en idioma español, vol. 3659 (16 de junio de 1903). 
a la generalidad de esa población que por razón de su número ${ }^{43}$ tiene el derecho de gozar de esas ventajas que da la publicidad". ${ }^{44}$

La reparación de los letreros y rótulos que estuvieran desgastados, la corrección ortográfica y la vigilancia moral de los mensajes también fueron objeto de atención por parte de las autoridades. ${ }^{45}$ Con el paso de los años, la incorporación de nuevas tecnologías en los anuncios publicitarios ocupó la atención de los encargados del Ayuntamiento. Las propuestas publicitarias que se radicaron en sus oficinas evidencian la evolución de la ciudad moderna; la incorporación de elementos como el cinematógrafo y la luz eléctrica expandió las fronteras de la imaginación de una nueva clase de profesionales, los agentes publicitarios. ${ }^{46}$

En consecuencia, se pueden encontrar desde proyectos que planteaban el aprovechamiento de la incipiente infraestructura urbana, como los faroles de luz, para, de esta manera, descongestionar de carteles los ya saturados muros; hasta la utilización de los últimos adelantos tecnológicos, como la instalación de carteles con imágenes en movimiento. Un seguimiento detallado a estas propuestas nos permite delinear el moderno paisaje urbano

43 De acuerdo con cifras proporcionadas por Judith de la Torre, "La superficie total del Distrito Federal era de 152910 ha. De acuerdo con el censo de 1895 contaba con 476433 habitantes, de los cuales 329774 vivían en la ciudad; en 1900, la población total de los municipios había aumentado a 541 516, mientras que la de la ciudad registraba 344721 . El mayor incremento se produjo en 1910: 720753 pobladores en el Distrito Federal y 471066 en la ciudad”. Torre, "La ciudad de México", p. 12.

${ }^{44}$ Sin título, en Diario Oficial (19 jun. 1903).

${ }^{45}$ AHDF, $P l$, exp. 151, Andrés Padilla pide se le nombre Inspector de Letreros de la ciudad, vol. 3660 (1915).

${ }^{46}$ Bunker señala que "el negocio de la publicidad durante el porfiriato fue remarcablemente descentralizado y desprofesionalizado [...]”. Para 1899 identifica nueve compañías de publicidad exceptuando agentes de publicidad individuales como José D. Gayosso y David Camacho. "En la siguiente década continuaron abriendo nuevas firmas incluyendo John H. Greaves \& Co., la Compañía de Anuncios Mexicana S. A. y la Empresa Explotadora del Anuncio de Movimiento sobre Vehículos”, Bunker, Creating Mexican, p. 63. 
que estaba emergiendo y al cual las tiendas departamentales dieron importantes trazos por medio de su activa participación en la renovación del discurso publicitario.

Podemos comenzar entonces con el proyecto de los señores Vicente Moyano y José G. Alonso, quienes se dirigieron al Ayuntamiento de la ciudad para comunicar que habían "ideado un sistema de anuncios, consistente en cuatro escudos o chafras [sic] de cualquier clase de metal, convenientemente adheridas a las columnas y pescantes de los faroles del alumbrado público, conforme a los modelos y diseños que tenemos la honra de acompañar". ${ }^{47}$ Con este proyecto se buscaba contribuir al ornato de la ciudad, dando vida a los faroles de luz que ya estaban ubicados a lo largo y ancho de las calles capitalinas.

\section{Imagen 1}

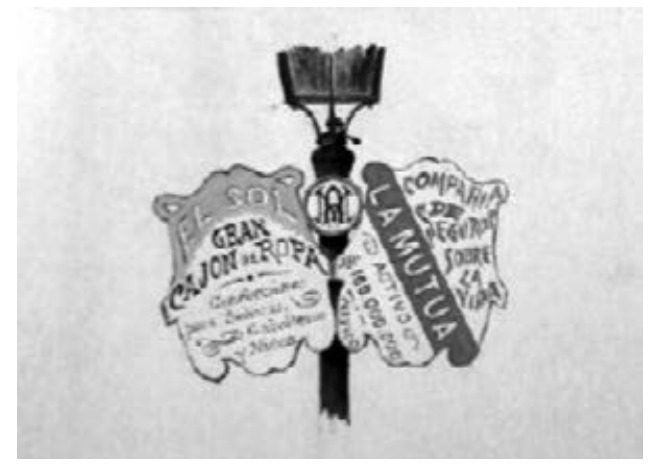

Propuesta de faroles con anuncios publicitarios, 1891.

El argumento más utilizado en la justificación de estos proyectos era la emulación del estilo de las capitales más reconocidas

47 AHDF, $P l$, exp. 64, Vicente Moyano y José G. Alonso piden permiso para colocar anuncios en las columnas y pescantes de los faroles del alumbrado, vol. 3659 (19 de septiembre de 1892). 
a nivel mundial. Era en París, Londres o Nueva York donde la publicidad se fundía con el buen gusto y la elegancia, por lo que si la Ciudad de México quería estar a ese nivel, no había otro camino que la imitación. Así lo plantea la solicitud realizada por la compañía de Federico Bodet: "haciéndose necesario establecerse en la ciudad una agencia de avisos estilo europeo moderno que al mismo tiempo sirven de ornato". ${ }^{48}$ Otro argumento a su favor se basaba en los ideales de progreso, "en todos los países ilustrados del mundo supongo está considerado el anuncio como uno de los principales factores para favorecer el desarrollo comercial". ${ }^{49}$ Finalmente, otras solicitudes fueron más específicas al señalar los lugares que inspiraron su propuesta, como la del señor Antonio Valle, de nacionalidad española, quien "solicita permiso para instalar unos anunciadores, el modelo está tomado de las capitales de Francia, España y Estados Unidos". ${ }^{50}$

Como el objetivo de esta publicidad callejera era acompañar el recorrido de los transeúntes ${ }^{51}$ a la vez que los actualizaba en las novedades de los almacenes, la recurrencia de los proyectos publicitarios de instalar "postes anunciadores" y tableros itinerantes es apenas obvia. A propósito de los tableros, éstos debían ser de madera, para evitar el daño en las paredes de los edificios y además este tipo de estructuras permitirían cambiar regularmente los anuncios. Esto indica una transformación en la percepción del tiempo publicitario, pues los tableros enmarcaban la idea de mensajes pasajeros que cambiaban según las tendencias y necesidades.

${ }_{48}$ AHDF, $P l$, exp. 74, Federico Bodet y Cía. piden permiso para establecer una agencia de anuncios, vol. 3659 (23 de abril de 1895).

49 AHDF, Pl, exp. 63, Díaz Alberto pide permiso para el establecimiento de torres con anuncios comerciales, vol. 3659 (18 de noviembre de 1892).

50 AHDF, Pl, exp. 69, Antonio Valle y Cía. pide autorización y privilegio para establecer anunciadores, vol. 3659 (1893).

51 En la ciudad moderna, "El transeúnte es un ser disuelto o en disolución, es como una suerte de membrana esponjosa que atrae sensaciones, proclive siempre a la recepción de mensajes provenientes del medio en el que se mueve”, en Acosta, Las experiencias, p. 13. 
Imagen 2

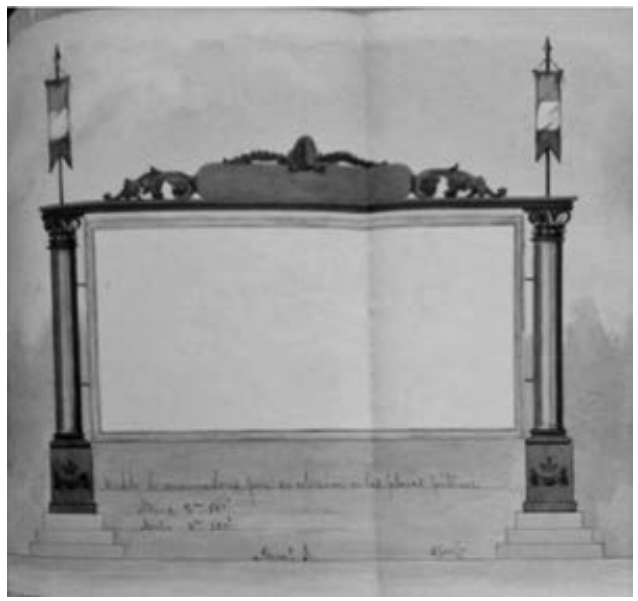

“Tablero anunciador” Propuesta de Antonio Valle, 1893.

La búsqueda de un lugar propio, destinado exclusivamente a los anuncios publicitarios, hizo que algunos personajes fueran más osados con sus propuestas. Por ejemplo, Alberto Díaz propuso la construcción de unas "torres anunciadoras". En su propuesta el señor Díaz explicaba que “[las torres] serán todas de fierro en esqueleto y los tableros respectivos se cubrirán durante el día con lienzo, papel o madera hasta tanto que se les ponga cristales, en cuyo caso, subsistirán así permanentemente y podrán ser iluminadas en su interior con luz eléctrica hasta las doce de la noche". ${ }^{52}$ La intención era instalar estas torres en las principales calles de la ciudad, así:

Plaza de la Constitución: una en el costado oriente, una en el suroriente y otra en el sur; esquina de Santa Teresa frente al correo;

52 AHDF, $P l$, exp. 63, Díaz Alberto pide permiso para el establecimiento de torres con anuncios comerciales, vol. 3659 (18 de noviembre de 1892). 
Calzada de la Reforma; Empedradillo y 5 de mayo; Esquina 5 de mayo y Vergara; Esquina de la Canoa frente al congreso; Esquina Guardiola y San Juan de Letrán; Esquina Mariscala y Santa Isabel; Esquina Independencia y San Juan de Letrán; Plazuela de Santo Domingo; Esquina San Fernando y Avenida Oriente; Calzada de San Cosme; Cordobanes frente al Palacio de Justicia. Si alguno de estos lugares no fuere de la aprobación del ayuntamiento se sustituirá por otro de común acuerdo. ${ }^{53}$

Por medio de estas propuestas, de las cuales no sabemos si se ejecutaron o no, podemos comprender la manera en que la publicidad tradujo el deseo de consolidación de una ciudad moderna, cuyo parámetro rector fue tomado de las principales ciudades europeas, sobre todo Londres y París. La influencia francesa fue evidente, los anuncios estuvieron inspirados en los affiches parisinos, los cuales fueron muy utilizados debido al éxito de la técnica cromolitográfica que permitía la ilustración a color y la impresión a gran escala y a bajo costo. ${ }^{54}$ En los lugares donde se empleó esta estrategia, los afiches fueron, además de mensajes publicitarios, piezas de arte desarrolladas por “artistas de diversas partes del orbe [quienes] se empeñaron en llevar a cabo un revolución en las artes visuales y en los conceptos tradicionales vigentes desde la modernidad renacentista" ${ }^{55}$

No obstante, para la época, en los avisos publicitarios mexicanos primó el pragmatismo por sobre la estilización artística, sin dejarla de lado completamente. El propósito principal era atraer e impactar, pero esto debía realizarse de manera económica y debía ser masivo, es decir, llevar su mensaje a sus potenciales clientes, familias acomodadas económicamente y los difusos

53 AHDF, $P l$, exp. 63, Díaz Alberto pide permiso para el establecimiento de torres con anuncios comerciales, vol. 3659 (18 de noviembre de 1892).

${ }^{54}$ Parafraseado del original en francés en Archives Départamentales de l'Aude, L'aude, p. 15.

55 OrTiz, Imágenes del deseo, p. 29. 


\section{Imagen 3}

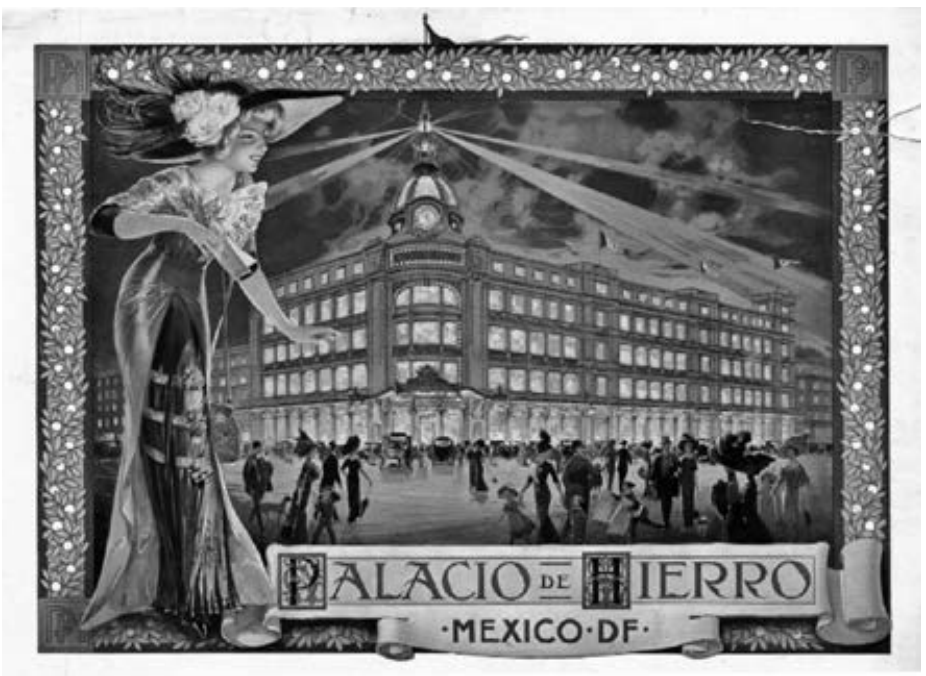

CMDLV- Recuerdo de la reinauguración de El Palacio de Hierro, 1911. Foto cortesía de Musée de la Vallée, Barcelonnette, Francia.

sectores medios, compuestos particularmente por profesionistas. Esta eficacia del mensaje puede encontrarse en los carteles de los grandes almacenes, los cuales por lo general utilizaban pocas palabras, a veces apenas se mencionaba el nombre y la ubicación de la casa comercial. Dado el caso, también podía comunicársele a la clientela la época de las "baratas” en sus tiendas. El uso de la imagen era escaso, salvo en algunas excepciones como la reinauguración de El Palacio de Hierro, como lo muestra la imagen 3. Dependiendo de la inversión que hacía la tienda, en ocasiones los anuncios mostraban diferentes fuentes tipográficas; esto puede entenderse como una estrategia de mercadeo en la cual la variedad tipográfica podía llamar la atención de los transeúntes y grabarse en su memoria.

Desde esta lógica, las facilidades que ofrecían las nuevas tecnologías permitieron a los desarrolladores de la publicidad 
implementar atracciones que cautivaran a más público. La adopción de imágenes en movimiento es un claro ejemplo de esto. Los anuncios que se movían, además de brindar un aire atractivo y tecnológico al mensaje, abonaban a la idea de embellecimiento y avance de la urbe. Así encontramos que en 1912 Rafael Vilella propuso la instalación "en las fachadas de las casas de aparatos anunciadores [...] poniendo al servicio público unos aparatos mecánicos movidos por electricidad que exhiben los anuncios en constante movimiento". .6

Pero quizá el proyecto más ambicioso que identificamos en este trayecto publicitario fue el que planteó un centenar de almacenes, incluyendo tiendas departamentales como El Palacio de Hierro, la Reforma del Comercio, El Puerto de Liverpool, entre otras, las cuales propusieron la colocación, frente a sus locales, de rótulos eléctricos. La innovación se explica por partida doble; en primer lugar, es un proyecto pionero que se presenta de manera compartida por los socios de los comercios de la ciudad, en un afán por homogeneizar el formato de los anuncios publicitarios. Por otro, la utilización de la electricidad, la cual, además de enviar un mensaje modernizador a los clientes, contribuía en el embellecimiento y seguridad de las calles de la capital. La propuesta era específica en lo que respecta al tamaño y distribución de los avisos:

Los rótulos se extenderán horizontalmente del edificio de una longitud que no interrumpa la vista y de un máximum que no exceda de $2 \mathrm{mts}$. Dichos rótulos además de servir al fin del anuncio que nos proponemos serán hermosos en su aspecto y seguros, pues estarán construidos de hierro forjado o instalados según las reglas que al efecto tenga a bien expedir ese mismo honorable gobierno. ${ }^{57}$

${ }^{56}$ AHDF, $V P A$, exp. 570, Rafael Vilella Guzmán pide permiso para establecer en las fachadas de las casas aparatos anunciadores mecánicos, vol. 1978 (16 de mayo de 1912).

57 AHDF, VPA, exp. 616, Varios comerciantes solicitan permiso para colocar rótulos eléctricos en sus establecimientos, vol. 1978 (9 de agosto de 1912). 
El Ayuntamiento respondió de manera favorable ante esta solicitud. De hecho, causó tal impacto que en seguida se expidió un reglamento sobre "letreros luminosos"; en éste se les definió como: "cualquier letrero, palabra, modelo, firma o representación usado en la forma de avisos, anuncio o dirección, iluminado con electricidad, instalado en cualquier edificio de la ciudad de México". ${ }^{58}$ Entre los principales términos y condiciones para su instalación se mencionaba que: "Ningún letrero luminoso sobresaldrá en ningún caso más que la anchura de la banqueta, pudiendo alcanzar como máximo hasta dos metros de altura; los letreros serán construidos a prueba de fuego y estarán bien asegurados al edificio [...]".59 Además, por supuesto, se exigía el correcto uso de la ortografía y el buen uso de la moral.

Aunándose a la utilización de nuevas tecnologías, encontramos que el fonógrafo también inspiró la creación de novedades publicitarias. Algunos maniquíes que tenían un sistema fonográfico en su interior fueron ubicados en la entrada del almacén para anunciar las novedades del día. Aún más creativo fue Domingo Arámburu, quien inventó un perro mecánico que podía recorrer las calles "ladrando" el mensaje publicitario a partir de un sistema fonográfico incorporado en su diseño. ${ }^{60}$

Hasta aquí podemos identificar un proceso de cambio continuo en las formas y usos de los anuncios publicitarios exhibidos en las calles citadinas. ${ }^{61} \mathrm{Si}$ bien hacia finales del siglo XIX la

58 AHDF, VPA, exp. 616, Varios comerciantes solicitan permiso para colocar rótulos eléctricos en sus establecimientos, vol. 1978 (9 de agosto de 1912).

59 AHDF, VPA, exp. 616, Varios comerciantes solicitan permiso para colocar rótulos eléctricos en sus establecimientos, vol. 1978 (9 de agosto de 1912).

60 "Arámburu invented a mechanical dog designed to walk the city, play music from a phonograph inside, and dispense ads from his mouth.” Citado en Bunker, Creating, p. 67.

61 Es importante señalar con Novo que, antes de los carteles, las calles de la ciudad habían sido tomadas por un variopinto grupo de vendedores ambulantes, quienes por medio de la oralidad, expresaban formas populares de 
tendencia se orientaba a aprovechar los recursos que la ciudad misma ofrecía, como los postes de luz, notamos que entrado el siglo xx la innovación tecnológica marcó la pauta en lo que respecta a anuncios luminosos y llamativos. Sin embargo, los mensajes contenidos en los avisos no tuvieron cambios notorios; la persistencia de la brevedad de los textos y la simpleza del diseño fueron las características generales de esta estrategia comercial.

En contraste, la prensa, como lo veremos más adelante, se permitió el despliegue de la creatividad, el arte y los mensajes más complejos. Pero, antes de adentrarnos en las páginas de la prensa ilustrada del porfiriato, es perentorio retomar la idea de que la publicidad "es literalmente un bacer público, una modalidad comunicativa ya consolidada en la colectividad que utiliza varios medios de comunicación para dar a conocer productos, sugiriendo una imagen favorable de los mismos y de sus contextos de utilización, y estimulando su compra y consumo". ${ }^{62}$ De esta manera, es necesario rescatar otras formas publicitarias, que implicaron la "toma de las calles" como estrategia llevada a cabo por las tiendas departamentales para darse a conocer ante los habitantes de la ciudad.

\section{LA PUBLICIDAD SE MUEVE EN CARRO}

Debido al proceso de consolidación de los grandes almacenes en la capital mexicana durante la primera década del siglo xx, la promoción y venta de las mercancías de estos comercios no podía limitarse a las vitrinas o a los anuncios instalados en las calles. Para llegar a un espectro más amplio de ciudadanos fue necesaria la utilización de otros recursos que permitieran expandir el negocio; fue así como empezaron a utilizarse los

comunicación como la sátira, las alusiones, los chistes, etc., y cuyo mensaje tenía un fin comercial, Novo, Apuntes.

62 Pérez Tornero, La seducción, p. 51. 
carros repartidores, que eran "coches destinados a la entrega de mercancías [...] los primeros que se vieron no sólo eran de marca francesa, sino que además pertenecían a dos casas comerciales establecidas por nuestros compatriotas: la fábrica de cigarros El Buen Tono y El Palacio de Hierro". ${ }^{63}$

Lo interesante de estos “anuncios móviles” era que tomaban las mismas rutas del transporte público, es decir, que podían alcanzar la mirada de sectores de la población que usualmente no visitarían los grandes almacenes. La ampliación del espacio de propagación del mensaje aumenta también el número de espectadores que accederán al mismo. Así, "la publicidad, en términos generales, busca entre dos estrategias opuestas, la estética y la pragmática, ya que con la seducción se garantiza el impacto en el individuo, pero además se tiene que ser eficaz para conseguir su objetivo de modificar comportamientos y actitudes" ${ }^{64}$ Entonces, si entendemos la publicidad como un sistema de comunicación de doble vía, en el cual el anunciante espera una respuesta favorable del destinatario, resulta muy pertinente preguntarse sobre la recepción del mensaje.

La publicidad, tanto de las vitrinas como de los muros en las calles, llegaba sólo a aquellos peatones que pasaban por esos lugares. Es decir, personas que intencionalmente debían recorrer esa ruta para llegar a su destino, fuera por motivos personales o laborales (como los mismos empleados de los comercios) y, por supuesto, era una publicidad diseñada para los propios clientes que se deleitaban con los ojos antes de comprar. Tanto una como otra estrategia enviaban mensajes itinerantes, pues, por ejemplo, los carteles se instalaban por cierto tiempo en las calles, lo que con seguridad marcó la subjetividad de los transeúntes, quienes construyeron sus mapas mentales atendiendo a las imágenes que diariamente veían expuestas. Las tiendas, sus anuncios y

63 Gortari y Hernández (comps.), Memoria, p. 127.

64 Pérez Tornero, La seducción, p. 54. 
las vitrinas se convirtieron en referentes de la población en la construcción de su experiencia urbana.

Volviendo al tema de la recepción del mensaje publicitario, es válido preguntarse a quién estaba dirigida la publicidad de los carros repartidores. Paradójicamente, aunque la publicidad de los carros podía alcanzar un radio de recepción mayor, considerando que se movían ampliamente por la ciudad, encontrando a su paso sujetos heterogéneos en cuanto género, clase social y edad, lo más probable es que la publicidad calara sobre todo en los vecinos de las casas a donde llegaba el carro a entregar las mercancías solicitadas, quienes podían observar el tipo de productos que llegaban. Para el transeúnte, el paso del carro repartidor daba un mensaje muy vago del almacén, pues la publicidad de los carros repartidores era muy sencilla, apenas podía identificarse el nombre del comercio al que pertenecía el vehículo, por lo que el código publicitario no apuntaba a seducir para la compra; eso sí, buscaba consolidar una marca.

La estrategia de llevar las mercancías "a domicilio" contribuía a la propagación de la idea de distinción, enmarcada en el hecho de que las tiendas departamentales llevarían hasta la puerta de la casa los productos comprados. Por otro lado, la entrega a domicilio favorecía al almacén que cobraba por este servicio y a la vez difundía el nombre del almacén y, también, beneficiaba al comprador pues ostentaba su compra al vecindario. Este presupuesto se basa en la idea de que las casas estaban situadas en zonas residenciales exclusivas, que para la época se encontraban en algunas calles céntricas, cercanas a la Avenida Reforma. De acuerdo con Judith de la Torre, "en 1902 aparecieron tanto la Condesa como la Roma, ésta dividida en Norte y Sur. Dos años más tarde, el abogado Rafael Martínez de la Torre fundó la Cuauhtémoc en terrenos correspondientes a la Hacienda de la Teja y, en 1906, surgió la Juárez". ${ }^{65}$

65 Torre, “La ciudad de México”, p. 17. 
Los carros repartidores fueron cambiando de apariencia, de acuerdo con los progresos tecnológicos, al tiempo que la ciudad se fue extendiendo en torno a las rutas de transporte. Ariel Rodríguez Kuri confirma para el caso de la Ciudad de México que la "expansión territorial siguió lo que un urbanista ha llamado los ejes de metropolización, es decir, un poblamiento organizado según las líneas y redes de los equipamientos urbanos, sobre todo, en este caso, de las líneas de los tranvías". ${ }^{66}$

En contraste con la estrategia publicitaria de los carros repartidores, la cual pretendía acaparar la mirada dispersa de los habitantes de la ciudad, existió un acto que aprovechó la concentración de las personas en un solo lugar. Este era el desfile de carros alegóricos, que atraía la atención de los personajes capitalinos. Esta exhibición era una celebración que marcaba la llegada de la primavera y fue denominada la "fiesta floral"; el Ayuntamiento de la ciudad era el encargado de la organización de esta conmemoración de la "época más colorida del año". Oficialmente, la fiesta floral fue definida como una

Celebración popular para todas las clases sociales y que sirve para congregar en fraternal consorcio a todos los habitantes de la metrópoli, sin distinción de sexos ni nacionalidades ni tamaños; fiesta encantadora y entusiasta que proporciona honrado trabajo a los numerosos floricultores del Distrito Federal que agotan su materia prima en una batalla donde los dardos son las mismas flores y los mejores combatientes las damas, hermanas de esas flores. ${ }^{67}$

Dentro de su extenso programa de festejos sobresalía el concurso de "carros alegóricos" en cuyo desfile participaban los vehículos inscritos previamente. Desde 1891 se abrió una categoría

${ }_{66}$ Rodríguez Kuri, Historia del desasosiego, p. 27. Además, un estudio detallado sobre el crecimiento de la Ciudad de México puede encontrarse en Barbosa y González, Problemas.

67 Sin título, en Diario Oficial (2 mayo 1905). 
exclusiva para los coches de las casas comerciales. La condición para participar en dicho certamen era decorar el coche en alusión a la alegría primaveral; las directrices eran claras: "el adorno de los coches será de flores naturales: pudiendo admitirse de telas y listones finos, pero dominando el de flores naturales". ${ }^{68}$ En el desfile, los coches transitaban por las céntricas calles de la capital incluyendo las principales calles del comercio, aledañas al Zócalo. Esta situación era aprovechada por las tiendas, que también decoraban las vitrinas con maniquíes que representaban a las "bellas damas" en las festividades. Por supuesto, la oportunidad no era desaprovechada por las tiendas, las cuales, además de publicitar el cambio de temporada, hacían alusión a la fiesta floral como el acto ideal para lucir bien.

Junto con la celebración de la primavera, podemos encontrar otro tipo de festividades oficiales que sirvieron como trampolín para la promoción del buen nombre y de las mercancías de los grandes almacenes. Por ejemplo, la conmemoración del Centenario de la Independencia ayudó a difundir la fama de los grandes almacenes. El programa de festejos incluyó un "día del comercio", en el cual participaron las tiendas en un majestuoso desfile de carros alegóricos. El beneplácito de las autoridades y lo imponente de los coches decorados nos deja claro no sólo la presencia de las tiendas departamentales en el panorama urbano sino la influencia francesa en el imaginario cultural de la época. Esto se confirma con la opinión pública construida desde la prensa. Así, El Imparcial se refería a la participación en el acto de dichas tiendas en los siguientes términos: "Los mexicanos, cuando se trata de fiestas francesas se unen a los hijos de la gran Francia para hacerlas más brillantes; ahora toca a estos unirse a nosotros para correspondernos, por eso es que confraternizamos con ellos". 69

${ }^{68}$ Sin título, en Diario Oficial (9 abr. 1907).

${ }^{69}$ Sin título, en El Imparcial (5 sep. 1910). 
Para esta celebración, los aparadores también se vistieron de gala y captaron la atención de los transeúntes. El Mundo Ilustrado registró las siguientes impresiones:

El primer número no oficial de las actuales fiestas han sido las iluminaciones de algunos edificios y la ornamentación de aparadores de casas de comercio, entre los cuales se destaca los de 'La Gran Sedería’ de los Sres. Julio Albert y Cía., Sucrs. [...] Tres son los aparadores que cautivan la atención, uno del centro es una sugestiva apoteosis de la independencia encuadrada por un lujoso dosel tricolor, simbolizada por una bella figura de mujer que representa la Patria oprimida, y otra figura, no menos hermosa, coronando con laureles al inmortal cura Hidalgo. ${ }^{70}$

La participación de las tiendas departamentales deslumbró al público por su imponente presencia. Sobre El Palacio de Hierro se dijo que

[...] llamó poderosamente la atención el carro de la primera casa comercial de ropa en el país [...]. Una descubierta de heraldos pregonaban el nombre y la fama de los grandes almacenes, llevando el nombre de 'El Palacio de Hierro' en los banderines blancos de sus vibrantes trompetas que en alegre sonata iban llamando la atención de los espectadores.

El Centro Mercantil no se quedó atrás, y fue sin duda uno de los más elegantes "[pues] presentó un hermoso carro estilo Luis XV, en su frente se destacaba un grupo de ángeles llevando coronas de flores. Estas figuras de yeso daban un bonito aspecto". ${ }^{71}$

70 Sin título, en El Mundo Ilustrado (11 sep. 1910).

${ }^{71}$ La descripción detallada se encuentra en El Imparcial (5 sep. 1910). 
De la misma manera en que lo señala Valerio Ulloa para el caso de Guadalajara, las tiendas capitalinas "anunciaron sus productos en diversos periódicos y revistas de distinto signo político, ideológico y religioso, pues el fin de dicha publicidad fue principalmente económico". ${ }^{72}$ La prensa, después de los carteles, es quizá uno de los métodos publicitarios más tradicionales. No obstante, por estar a la vanguardia de los medios de comunicación, en sus páginas corroboramos que el despliegue artístico, el uso de la imagen y la riqueza y variedad de los mensajes cobraron un protagonismo inusitado, reafirmando además que el sentido de la vista y la función de la mirada eran relevantes para la percepción y construcción de las subjetividades, ante un mundo urbano en pleno crecimiento y desde una ciudadanía en ciernes.

La modernidad en los periódicos se manifestó, entre otras cosas, en los avances en la litografía, las cuales permitieron a la prensa avanzar hacia el camino de los altos tirajes a bajo costo. Puede decirse que la difusión masiva a precios módicos fue el precepto que acompañó la idea de la circulación de la publicidad por medio de la prensa. En este contexto, la expansión de la publicidad de los grandes almacenes revestía las páginas de las publicaciones diarias con un halo de civilidad y de anhelos de elegancia y decoro; era en palabras de Ortiz, la representación de la "bella época". ${ }^{73}$

La situación de la prensa moderna fomentó el crecimiento de la publicidad a finales del siglo xIx en México. Ariel Rodríguez Kuri señala que la aparición de El Imparcial ${ }^{74}$ determinó la

72 Valerio Ulloa, “Discursos”, p. 321.

73 OrTIz, Imágenes del deseo, pp. 40-41.

74 El trabajo de Hellion, Exposición permanente, explora con detalle la relación comercial entre el periódico El Imparcial y la publicidad de las tiendas por departamento en la ciudad de México. 
consolidación de la prensa metropolitana en el país. Retomando el modelo de Gunther Barth, este proceso se caracterizó por "la producción industrializada, el abaratamiento de precios y aumento de la cantidad de ejemplares, la ampliación de la denominada crónica o el relato de los hechos y la cobertura cada vez más amplia de los detalles de la vida cotidiana de la gran ciudad". ${ }^{75}$ De esta manera, la relación de la publicidad con la prensa era beneficiosa para las dos partes de la transacción: por un lado, el almacén incrementaba sus ventas, mientras que, por el otro, el periódico se veía retribuido con el pago de las inserciones publicitarias y dejaba de depender de los suscriptores.

Aunque pudiera parecer imprescindible la relación entre la prensa y los socios de las tiendas que la usaban para publicitarse, en 1922 Desiderio Marcos publicó un folleto en donde exhibía la necedad de algunos comerciantes que veían la inversión en anuncios en prensa como dinero perdido. Al respecto argumenta: "el comerciante que para fomentar las ventas ordinarias de su establecimiento pone únicamente dos anuncios mensuales o uno al principio y otro al fin de cada estación, en un periódico, así sea éste el de más abundante circulación, pierde lastimosamente su tiempo y su dinero". ${ }^{76}$ Esto conduce a nuestro autor a argumentar que el presupuesto de gasto para publicidad, de cualquier casa que se prestara de ser seria y sólida, debía ser constante y generoso.

En paralelo con el crecimiento y la consolidación de la prensa como difusor publicitario, debe contemplarse el proceso de profesionalización del publicista. Para la segunda década del siglo xx los publicistas eran considerados "un elemento importantísimo del comercio", debido a que su presencia social estaba ligada al diseño de los anuncios que pretendían propiciar las ventas; se consideraban "valiosos auxiliares del comercio [por

75 Rodríguez Kuri, “El discurso del miedo”, p. 699.

${ }^{76}$ Marco, El anuncio en México, p. 11. 
tanto] deben ser muy bien remunerados en su trabajo, y de una manera directa por los anunciantes". ${ }^{77}$

Al parecer, y desde años previos, las grandes tiendas sí tenían claro el precepto que señalaba Marcos: "el periódico es algo así como un aparador abierto día y noche y ambulante". ${ }^{78}$ Puede decirse, además, que el tamaño, prestancia e importancia del almacén podía medirse por la frecuencia de los avisos, pero también por la cantidad y la variedad de ofertas que se anunciaban. Además, otro factor importante era el tamaño y la ubicación en el periódico. ${ }^{79}$ Por ejemplo, El Palacio de Hierro, que era una de las tiendas más grandes y prestigiosas, por lo general ocupaba una página completa y complementaba su mensaje con ilustraciones de las mercancías.

Aunque se denota una casi total prevalencia de los negocios franceses, también hay otros que podrían ser de origen español o mexicano. La tabla 1 fue elaborada a partir de la revisión de prensa; el orden obedece a la frecuencia con que aparecían los avisos de propaganda de estos comercios, y aunque no busca exponer datos exhaustivos de la tendencia de aparición publicitaria, sí quiere ilustrar la creciente y variopinta oferta con la cual se encontraba el lector y posible comprador en aquella época.

Los anuncios también nos permiten identificar la variedad de mercancías que se ofrecían en las tiendas. Particularmente, los grandes almacenes actuaban bajo el canon de la venta de artículos diversos, a bajo costo. Por esta razón, el consumidor podía encontrar en un mismo lugar productos relacionados con el vestido, artículos personales, accesorios y también secciones dedicadas a la decoración y mobiliario de las casas. Pero quizá

77 Marco, El anuncio en México, p. 28.

78 Marco, El anuncio en México, p. 18.

79 Además de las páginas de la prensa, se sabe que las tiendas departamentales en ocasiones ampliaron su promoción por medio de inserciones pagadas en distintas publicaciones seriadas como almanaques, directorios y folletos. GamboA, "Los comercios", p. 166. 


\section{Tabla 1}

LISTA DE CASAS COMERCIALES CON MAYOR PRESENCIA

PUBLICITARIA, 1891-1915

\begin{tabular}{ll}
\hline Casa comercial & Propietarios \\
\hline El Palacio de Hierro & Joseph y Jules Tron \\
El Puerto de Veracruz & Léon y Antoine Signoret \\
Las Fábricas Universales & Alexandre Reynaud \\
El Centro Mercantil & Sébastien Robert y Joseph Pinoncely \\
El Surtidor & Primitivo Pérez \\
La Valenciana & Calixte Caire y Théodore Aubert \\
El Progreso Mercantil & A. Levy y Martin \\
La Ciudad de Londres & Édouard Gassier \\
La Nueva Bella Jardinera & Alfonso M. Franck \\
La Samaritana & García Pérez y Cía. \\
Sorpresa y Primavera Unidas & J. Ollivier y Cía. \\
La Reforma del Comercio & Adolphe Rachaud Aubert y Augustin \\
& Garcin \\
El Puerto de Liverpool & Jean-Baptiste Ebrard \\
La Gran Sedería & Julio Albert y Cía. \\
Al Zafiro & F. Sánchez y Cía. \\
Le París Charmant & Mallet y Rangel \\
El Boulevard & M. del Prado \\
La Ciudad de Bruselas & S. Robert y Cía. \\
El Correo Francés & Mathieu Lambert \\
La Francia Marítima & Jean-Baptiste Fortoul y Desdier \\
Las Fábricas de Francia & Alfonso Caire \\
El Gran Oriental & P. y J. Jackes Sucrs. \\
\hline
\end{tabular}

FuENTE: elaboración propia a partir de la revisión de El Imparcial y El Mundo Ilustrado, 1891-1915.

la particularidad más relevante fue la adopción del precio fijo como método de intercambio comercial.

En los comercios más tradicionales, además de la tendencia a la especialización de los productos, era usual que la compra se efectuara a partir del regateo; esta actividad se realizaba de manera personal y consistía en solicitar una rebaja del producto sobre el precio sugerido por el vendedor. Aunque muchos clientes 
parecían verse beneficiados por tal actividad, lo cierto era que el tiempo invertido, junto con las rencillas que dejaba algún mal negocio, hacían de la actividad de comprar algo agotador y a veces injusto. Esta situación cambió cuando, a mediados del siglo xix, Aristide Boucicaut, un antiguo empleado de comercio que luego fue copropietario del primer grand magasin en París: Le Bon Marché, quiso aprovechar el alto volumen de existencias para vender barato, con bajo beneficio. Para agilizar la venta de las mercancías marcó cada artículo con su respectivo precio y revolucionó con ello el arte de vender, ganándose el epíteto de "padre del comercio moderno". ${ }^{80}$ De esta manera, el precio fijo fue otro de los atractivos que ofrecieron las tiendas por departamento en la Ciudad de México.

La novedad del precio fijo fue aprovechada en la publicidad de los grandes almacenes; en sus anuncios se señalaban claramente los "precios invariablemente fijos y muy cómodos" como un nuevo hábito del intercambio comercial. Por supuesto, toda regla tiene su excepción; en algunas ocasiones los precios se volvían negociables, esto era en los momentos de barata y de remate de las mercancías; en este caso los almacenes aclaraban tal situación: "Por cierre remate de mercancías sin precio fijo", ${ }^{11}$ o también, "señoras y señoritas, Gran realización de ropa, vestidos, sombreros, guantes, botines, etc. Ningún precio fijo". ${ }^{82}$

Además de competir por ser reconocidos como los almacenes con los mejores precios del mercado, también buscaban afianzarse como las tiendas más finas y prestantes de la ciudad. Contrario a lo que puede pensarse sobre estas casas comerciales que se proyectaban para un tipo de clientela acomodada económicamente, fue muy común la alusión a los precios bajos, con la

${ }^{80}$ Un estudio detallado sobre el impacto de la incorporación del precio único en el comercio lo realiza Enselme, Les magasins, p. 9.

${ }^{81}$ Sin título, El Imparcial (24 feb. 1910).

${ }^{82}$ Sin título, El Imparcial (5 ago. 1898). 
pretensión de atraer a un público más amplio. Una enumeración de expresiones encontradas en la prensa puede ilustrar este punto: "bueno, bonito y barato", "para comprar barato", "precios positivamente baratos", "la barata más colosal”, "precios módicos", "solamente dado es más barato", "precios nunca vistos", "precios moderados". 83

Por otro lado, las listas de precios también empezaron a hacerse populares en los avisos publicitarios; esta práctica sobre todo fue ejecutada por las tiendas más grandes, las cuales apostaban por vender mucho a precios módicos. El margen de ganancia no estaba en la venta individual de la mercancía sino en el balance global de las transacciones. De esta manera, páginas completas de los diarios eran ocupadas por detalladas enumeraciones de las mercancías y su precio correspondiente. Las mercancías, como evidencia de la cultura material de la época, son, a su vez, una puerta de entrada para conocer las nociones de comodidad, refinamiento, elegancia y buen gusto. Todas estas ideas se construían siguiendo el modelo de las élites sociales. ${ }^{84}$ Paradójica puede resultar esta afirmación si retomamos el análisis sobre la publicidad en las calles que se hizo antes. Sin embargo, la pretensión de "democratizar el mercado" dista

\footnotetext{
${ }^{83}$ Véanse El Imparcial y El Mundo Ilustrado, 1901 y 1907.

84 Aquí encontramos una suerte de paradoja, pues, si bien es cierto que la publicidad de las tiendas por departamentos estaba dirigida a un público específico: aquellos sectores sociales con la capacidad adquisitiva para poder seguir el ritmo de la moda. A su vez, sabemos que la moda es un fenómeno urbano y que enmarca procesos de movilidad social; sabemos que la venta al mayoreo de las tiendas departamentales buscaba llegar a otros lugares del país. Muchas de sus mercancías circulaban en tiendas más modestas en otros estados e incluso llegaban hasta zonas rurales por medio de los agentes de ventas. No obstante, esta circulación nacional-local no elimina la pretensión de distinción y buen gusto que buscaban los comerciantes y que deseaban reflejar en la publicidad. Al respecto véase Simmel, “The Philosophy”, 1923. Un ejemplo de la manera en que los barcelonnettes se abrían campo en el mercado regional lo podemos encontrar en el trabajo de VAlerio UlLOA, "Almacenes comerciales".
} 
mucho de las posibilidades reales de compra que tenían los receptores de la publicidad.

Otro elemento indicativo de la distinción de estas tiendas y que a su vez servía como canal publicitario es la oferta de las mercancías. El tamaño del almacén, característica que influía en su presencia en los periódicos, como ya se señaló, también influyó en la oferta, la cual estaba sujeta a la amplitud del almacén y al número de departamentos que poseía; eso sí, todos los productos enmarcaban la idea de alta calidad y de ser importados de las principales ciudades europeas. En general, gran parte de la oferta estaba dedicada a la ropa y a los accesorios femeninos: ${ }^{85}$ vestidos para cualquier ocasión, faldas, blusas (diferenciadas para el uso en la mañana, en la tarde y en la noche), abrigos, paletots, guantes, corsés, sombreros, sombrillas, etc. Para los hombres también había mercancías especializadas: trajes completos, sobretodos o abrigos, camisas, sombreros, pañuelos, corbatas, bastones, etc. De la misma manera se ofrecía un surtido variado de trajes y juguetes para niños y niñas; en algunos almacenes incluso se encontraban productos de interés para las iglesias y algunas tiendas, las más grandes, contaban con un departamento de muebles, teniendo ellas mismas sus propios talleres de carpintería.

Vemos así que tanto la variedad de la oferta como el tipo de enseres que se vendían nos hablan del progreso material de la sociedad y evidencian que la "asociación del consumo con los valores de la modernidad y el progreso estuvo relacionada de cerca con el nuevo estatus social" .86 Esta idea de diferenciación social fue el resultado de asumir como espejo a la burguesía de las principales ciudades del mundo, principalmente el reflejo francés marcó hábitos y estilos de vida en la clase acomodada mexicana. En suma, estos productos construían un ideal de buen

${ }^{85}$ Un estudio sobre las mujeres en la publicidad de las tiendas departamentales lo podemos encontrar para el caso chileno en Dussaillant, Las reinas de Estado.

86 OrTiz, “Casa, vestido y sustento”, p. 118. 
gusto que estaba ligado a las doctrinas llegadas de ciudades como Londres o París.

Como hemos insistido, uno de los recursos publicitarios más extendidos por los grandes almacenes fue el de definir el buen gusto y la elegancia como valores inseparables de sus productos; su uso y continua renovación significaba, para quien los consumía, estar un escalón más cercano a "la civilización”. La elección de las mercancías que se adquirían en palabras de Carmen Abad-Zardoya: ya fueran ropa u objetos, “obedecían a un mismo propósito: construir la imagen personal que se deseaba proyectar en sociedad, la de un sujeto 'de gusto' que demostraba dicha condición mediante sus hábitos de consumo". ${ }^{87}$

La incertidumbre por la llegada del siglo xx se manifestaba en un editorial de la época, en el cual se enunciaba la necesidad de conocer e ir al ritmo apresurado que imponía la moda. Ésta fungía como un medidor de éxito y vigilaba la capacidad de adquisición de las novedades que había que consumir para no quedarse atrás. Al respecto decía: "los pueblos cultos adoran cada día más a esa deidad hasta el punto que ya debe decirse que el país más civilizado es el que mejor acata los deliciosos caprichos de la Reina Moda". ${ }^{8}$

De esta manera, se construyó una “idea universal” de la moda, por lo cual es difícil diferenciar una ilustración publicada en París de una expuesta en la Ciudad de México. Las similitudes entre las ilustraciones, que por lo general acompañaban el anuncio publicitario en las páginas de la prensa, se explican no sólo por la circulación del discurso francés, como apoderado de los preceptos de la moda, sino porque de acuerdo con Roland Barthes el “vestido-imagen” estipuló la preeminencia de los dibujos o fotografías de la imagen femenina como el lenguaje más extendido para publicitar las últimas tendencias

87 AbAd-Zardoya, “El sistema de la moda”, p. 42.

88 El Imparcial (31 dic. 1899). 
en la indumentaria. Al vestido-imagen se suma, como estrategia narrativa de la propaganda, el "vestido escrito", es decir, las descripciones de los atuendos que mostraban las ilustraciones. Este fue el sistema lingüístico por medio del cual se extendió el mensaje de la moda. ${ }^{89}$

Tanto las mercancías, que daban cuenta de la cultura material de la época, como las imágenes utilizadas en la publicidad, enmarcaron la construcción de discursos que incitaban a un nuevo tipo de necesidades: la opulencia y el lujo o, en última instancia, la necesidad del ser visto. José Pérez Tornero menciona que:

La publicidad aparece, entonces, como un espacio de ensoñación, de discurso-sueño en que al receptor se le demanda latentemente que haga abstracción de su propia realidad y entre a la ficción del deseo realizado a través del consumo. El consumo se hace, pues, escenario de todas las realizaciones posibles, un medio [mágico] de apropiación de identidad y del "espíritu del tiempo".90

Para el caso de la publicidad de finales del siglo xix, una de las manifestaciones de este "espacio de ensoñación" fue el art nouveau, estilo artístico que exaltaba la figura femenina junto con la belleza de la naturaleza. La mayoría de los avisos publicitarios que incentivaban la compra de ropa y accesorios, tales como sombreros o sombrillas, utilizaron imágenes femeninas, marcando de esta manera una tendencia hacia el embellecimiento del género, mientras que, al mismo tiempo, se convertía a las mujeres en las principales consumidoras de las tendencias de la

89 BARTHEs, El sistema de la moda, pp. 17-19. En esta obra el autor diferencia entre el vestido escrito/vestido imagen/vestido real para señalar las diferencias semióticas de cada uno de los tres lenguajes señalados. Al respecto dice: "abro una revista de Moda: veo que trata de dos vestidos distintos. El primero es el que me presentan fotografiado o dibujado, es un vestido imagen. El segundo es el mismo vestido, pero descrito, transformado en lenguaje [...]”, p. 17.

90 Pérez Tornero, La seducción, p. 82. 
moda. Los corsés de la marca parisina À la Perséphone son un buen ejemplo de la utilización publicitaria del art noveau, además de que marcaron la pauta en lo que a la imagen femenina se refiere. El Palacio de Hierro resaltaba la oferta de esta marca como símbolo de distinción y belleza entre las mujeres.

Los hombres también tenían su propia promoción del buen gusto en el vestir. Dos tiendas se destacaron como especialistas en la moda masculina: High Life y New England. Dice Ortiz que "los patrones europeos en la moda, principalmente ingleses, establecieron que el traje fuera la vestimenta estándar, cuyo uso es en la actualidad ampliamente generalizado, aunque no pierde del todo su connotación burguesa". ${ }^{91}$ La diferenciación social que enmarcó el uso de ciertas prendas y accesorios en el vestir selló una jerarquía social visible en todos los lugares públicos: la iglesia, los parques, las calles, los almacenes, etc. Además, las imágenes que se utilizaban resaltaban el tipo masculino europeo.

El origen francés de los socios de la mayoría de las casas comerciales también contribuyó a la noción de "universalización de la moda”. Esta característica fue bien aprovechada por los anunciadores, quienes no tardaron en mencionarla en la publicidad de la prensa. Según esta idea, su condición de extranjeros, en particular provenientes de Francia, los hacía conocedores de primera mano de las manifestaciones de "buen gusto". Era usual encontrar junto al nombre de la tienda la identificación de los dueños y el tipo de sociedad mercantil que formaban. Algunos, como El Palacio de Hierro, incluso mencionaban el capital del que disponía la empresa. ${ }^{92}$

Otro elemento recurrentemente utilizado por los grandes almacenes para publicitarse fue la imagen del edificio, como puede observarse (imagen 4); el discurso de la modernidad "no sólo se

91 Ortiz, “Casa, vestido y sustento”, p. 124.

92 Durante un tiempo, El Palacio de Hierro se anunciaba como "Sociedad Anónima. 4000000 Capital Social”, en El Imparcial. 
apoyó en la palabra escrita sino en las imágenes: de la indumentaria, de los objetos y de los edificios". ${ }^{93}$ Patricia Martínez lo confirma aduciendo que

Un hecho muy importante [...] es que el elemento iconográfico principal de su publicidad fuera el edificio mismo, como lo podemos ver en las portadas o contraportadas de los catálogos, en las mencionadas postales o en los anuncios de periódicos y revistas. Desde 1891 hasta las primeras tres décadas del siglo xx, este testimonio se repitió: así tenemos diversas litografías y fotografías que nos permiten recrear la imagen del edificio y su transformación. La repetida representación del edificio en los medios impresos logró lo que los directivos se proponían: implantar su imagen en la percepción del público como icono de la modernidad en el comercio. ${ }^{94}$

El uso de las imágenes de los edificios es una evidencia de la búsqueda de una identidad publicitaria, que además buscaba calar en la memoria de los habitantes de la ciudad. En consecuencia, la aparición de los eslóganes fue parte natural de este proceso. Los lemas publicitarios buscaron quedarse en el subconsciente de los clientes, por medio de frases cortas y sonoras. Por ejemplo, El Palacio de Hierro exaltaba su "lealtad, honradez y eficacia", ${ }^{95}$ mientras que El Puerto de Veracruz ostentaba su estrategia de "vender más barato para vender mucho" "6 y Las Fábricas Universales por su parte hacían uso de la sonoridad de las tres 'b'; "no perdáis la ocasión de comprar bueno, bonito y barato". ${ }^{7}$

En fin, este recorrido por la publicidad de las tiendas departamentales en la Ciudad de México durante finales del siglo XIX

93 Valerio Ulloa, “Discursos”, p. 339.

94 Martínez, El Palacio de Hierro, p. 92.

${ }^{95}$ Sin título, en El Imparcial (10 jul. 1897).

${ }_{96}$ Sin título, en El Imparcial (3 jul. 1899).

97 Sin título, en El Imparcial (21 abr. 1900). 
Imagen 4

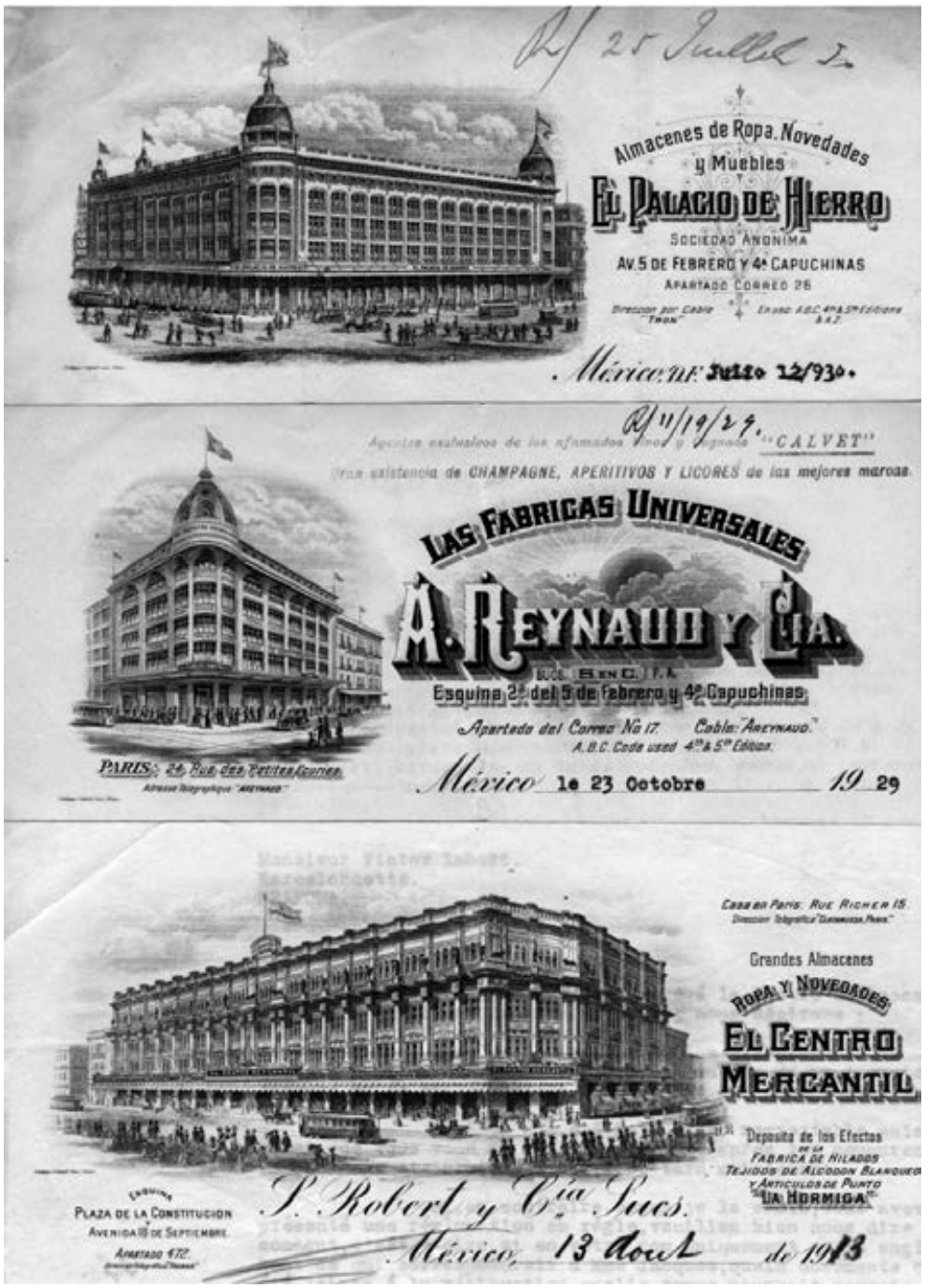

CMDLV- Membretes oficiales utilizados por algunas tiendas departamentales. Foto cortesía de Musée de la Vallée, Barcelonnette, Francia. 
y principios del xx, nos permitió reconocer la relevancia de la cultura visual en la formación de los hábitos de consumo de los habitantes de la urbe. Tanto el paisaje que se generó con los carteles en las calles como los estereotipos que se fundaron con los anuncios de la prensa, contribuyeron en la creación de sensibilidades y comportamientos sociales. De esta manera, "la iconografía publicitaria puede verse, entre otras cosas, como una crónica histórica de valor testimonial, la cual contiene, en un nivel profundo, toda la fuerza ideológica de la representación visual de mitos, arquetipos y símbolos del mundo occidental del siglo $\mathrm{xx}{ }{ }^{98}$

\section{CONCLUSIONES}

El artículo exploró la publicidad desde diferentes ámbitos y niveles de análisis. Así, los carteles en la calle, la decoración de las vitrinas, los recorridos de los carros alegóricos y los anuncios en la prensa formaron un peculiar paisaje urbano que influyó en el consumo de los habitantes de la capital mexicana.

Los mensajes contenidos en estas estrategias publicitarias se presentaron variados; para los carteles colgados en la vía pública encontramos que el pragmatismo orientó el establecimiento de tipografías llamativas con los datos básicos de la casa comercial. Por su parte, el impacto visual de los carros repartidores y alegóricos no requirieron el uso de palabras, más bien se eligió el uso de símbolos y de elementos cotidianos. Además, estos elementos tenían la ventaja de presentarse "en vivo y en directo" por lo que la percepción del color pudo impactar la mirada de los transeúntes.

Esto fue contrario a lo que sucedió con los anuncios de la prensa, los cuales solo en contadas ocasiones incorporaron el color como parte de la decoración de la propaganda impresa. En

98 Ortiz, “Casa, vestido y sustento”, p. 152. 
general, la estructura de un aviso de prensa tenía tres características: la identificación del almacén, algunos utilizaron lemas, una o varias ilustraciones que mostraban las mercancías o exhibían la construcción universal de un hombre y una mujer a la moda, por tanto, elegantes y agraciados y, finalmente, había una sección en la que se describían las mercancías y se señalaban sus precios. Por supuesto, no todos los anuncios eran iguales; el tamaño y la disposición en las páginas de la prensa señalaban tácitamente su importancia dentro de la ruta comercial.

Las nuevas relaciones comerciales generadas por la construcción de las tiendas por departamentos enmarcaron la construcción de imaginarios de consumo modernos relacionados con el lujo y el buen gusto. La publicidad, junto con los cambios apresurados de la moda, mantuvo a los clientes atentos a las innovaciones acostumbrándose de esta manera a consumir más artículos en menos tiempo. Tanto la publicidad en las calles como la impresa contribuyó en la percepción de un tiempo pasajero que estaba relacionado con los momentos en que debía consumirse cierto producto. Participar en estos tiempos de la publicidad contribuyó en la modificación de los hábitos de consumo de los habitantes de la capital mexicana.

\section{SIGLAS Y REFERENCIAS}

AHDF, $P l$ Archivo Histórico del Distrito Federal, fondo Policía de letreros, Ciudad de México, México.

AHDF, VPA Archivo Histórico del Distrito Federal, fondo Vías Públicas Aparadores, Ciudad de México, México.

ARFM Archivo Raíces Francesas en México, Ciudad de México, México, México.

Abad-Zardoya, Carmen, "El sistema de la moda. De sus orígenes a la postmodernidad”, en Emblemata, 17 (2014), pp. 37-59.

Acosta, Beatriz Elena, Las experiencias estéticas del transeúnte. Cartografías literarias, Bogotá, Universidad Nacional de Colombia, Sede Medellín, 2013. 
Archives départamentales de l'Aude, L'Aude s'affiche. La publicité dans l'Aude (1800-1960), Carcassonne, Archives Départamentales, 2014.

Arnaud, François, Anselme Charpenel, Léon Martin y André Signoret, Les Barcelonnettes au Mexique. Rècits et temoignages, Barcelonnette, Sabença de la Valeia, 2014.

Barbosa, Mario, "Capacitación y posición social de los empleados públicos de la ciudad de México a comienzos del siglo xx”, en Historia Mexicana, LxviII: 2 (270) (oct.-dic. 2018), pp. 747-783.

Barbosa, Mario y Salomón González, Problemas de la urbanización en el Valle de México, 1810-1910. Un homenaje visual en la celebración de los centenarios, México, Universidad Autónoma Metropolitana, 2009.

BARTHEs, Roland, El sistema de la moda, Madrid, Paidós Ibérica, 2003.

Benjamin, Walter, Libro de los pasajes, Madrid, Ediciones Akal, 2005.

Benjamin, Walter, París, Madrid, Casimiro Libros, 2013.

Béraud-Suberville, Geneviève, "Centinelas del pasado: del cajón de ropa a las tiendas-ancla”, en GAMBOA (coord.), 2008, pp. 247-280.

Berman, Marshall, Todo lo sólido se desvanece en el aire. La experiencia de la modernidad, México, Siglo Veintiuno Editores, 1991.

Bourdieu, Pierre, La distinción. Criterio y bases sociales del gusto, México, Taurus, 2002.

Bunker, Steven, Creating Mexican Consumer Culture in the Age of Porfirio Diaz, Albuquerque, University of New Mexico Press, 2012.

Carmagnani, Marcello, Las islas del lujo. Productos exóticos, nuevos consumos y cultura económica europea, 1650-1800, México, El Colegio de México, 2012.

Cosío Villegas, Emma, "La vida cotidiana”, en Daniel Cosío Villegas (coord.), La República restaurada. La vida social. Historia moderna de México, México, Hermes, 1974.

Dussaillant, Jacqueline, Las reinas de Estado. Consumo, grandes tiendas y mujeres en la modernización del comercio de Santiago (1880-1930), Santiago, Ediciones Universidad Católica de Chile, 2011. 
Enselme, Marguerite, Les magasins à prix uniques. Leur fonction dans le commerce de détail, Bourdeaux, J. Biére, 1936.

Faraut, François, Histoire de la Belle Jardinière, París, Belin, 1987.

GamboA, Leticia (coord.), Los barcelonnettes en México. Miradas regionales, siglos XIX y XX, México, Benemérita Universidad de Puebla, 2008.

GAмвоA, Leticia, "Los comercios de los barcelonnettes y la cultura del consumo entre las élites urbanas: Puebla, 1862-1928”, en Pérez Siller y CramauSELL (coords.), 2001, vol. II, pp. 159-178.

GAY, Peter, La experiencia burguesa. De Victoria a Freud. II. Tiernas pasiones, México, Fondo de Cultura Económica, 1986.

Gómez-Galvarriato, Aurora, Industry E Revolution. Change in the Orizaba Valley, Mexico, Cambridge, Harvard University Press, 2013.

Gortari, Hira de y Regina Hernández (comps.), Memoria y encuentros: la ciudad de México y el Distrito Federal (1824-1928), México, Instituto de Investigaciones Dr. José María Luis Mora, 1988.

Gouy, Patrice, Pérégrinations des “Barcelonnettes” au Mexique, Grenoble, Presses universitaires de Grenoble, 1980.

Gurney, Peter, "The Sublime of the Bazaar: A Moment in the Making of a Consumer Culture in Mid-Nineteenth Century England”, en Journal of Social History, 40: 2 (2006), pp. 385-405.

Hellion Puga, Rosa Denise, Exposición permanente: anuncios y anunciantes en El Mundo Ilustrado, México, Universidad Autónoma MetropolitanaAzcapotzalco, Instituto Nacional de Antropología e Historia, 2008.

Herrera Feria, María de Lourdes, “La puesta en escena de la modernidad y el progreso: la participación de México en las exposiciones universales de la segunda mitad del siglo xIx”, en Grabbylia, año 3, núm. 5 (2005), pp. 25-33.

Homps-Brousse, Hélène, L'aventure architecturale des émigrants barcelonnettes, France; Mexique, Barcelonnette, Musée de la Vallée, 2013.

Marco, Desiderio, El anuncio en México, México, Imprenta Nacional, 1922. 
Martínez Gutiérrez, Bertha Patricia, El Palacio de Hierro, arranque de la modernidad arquitectónica en la ciudad de México, México, Universidad Nacional Autónoma de México, 2005.

Miller, Michel, Au Bon Marché 1869-1920. Le consommateur apprivoisé, Princeton, Princeton University Press, 1981.

Morales, Humberto, "Los franceses en México: 1890-1910. Nueva revisión histórica: agentes comerciales, residentes e imperialismo informal”, en Signos Históricos, 17 (2007), pp. 174-223.

Novo, Salvador, Apuntes para una historia de la publicidad en la ciudad de México, México, Organización Editorial Novaro, 1967.

Ortiz Gaitán, Julieta, Imágenes del deseo, México, Universidad Nacional Autónoma de México, 2003.

Ortiz Gaitán, Julieta, "Casa, vestido y sustento. Cultura material en anuncios de la prensa ilustrada (1894-1939)”, en REYes (coord.), 2006, pp. 117-154.

Pérez Monroy, Julieta, "Modernidad y modas en la ciudad de México: de la basquiña al túnico, del calzón al pantalón”, en STAPLes (coord.), 2005.

Pérez Siller, Javier (coord.), México-Francia. Memoria de una sensibilidad común, siglos XIX Y XX, México, Benemérita Universidad de Puebla, El Colegio de San Luis, Centro de Estudios Mexicanos y Centroamericanos, 1998.

Pérez Siller, Javier y Chantal Cramaussel (coords.), México-Francia. Memoria de una sensibilidad común, siglos XIX y XX, México, Benemérita Universidad de Puebla, El Colegio de Michoacán, 2004, vol. II.

Pérez Tornero, José Manuel, La seducción de la opulencia: publicidad, moda y consumo, Barcelona, Paidós, 1992.

Pineda Cachero, Antonio, "Propaganda y publicidad comercial: un principio diferenciador", en Cuestiones publicitarias, 1: 12 (2007), pp. 107-128.

ReYes, Aurelio de los (coord.), Historia de la vida cotidiana en México, t. V, vol. 2, México, El Colegio de México, Fondo de Cultura Económica, 2006.

Rodríguez Kuri, Ariel, "El discurso del miedo: El Imparcial y Francisco I. Madero”, en Historia Mexicana, XL: 4 (160) (abr.-jun. 1991), pp. 697-740. 
Rodríguez Kuri, Ariel, Historia del desasosiego. La revolución en la ciudad de México, 1911-1922, México, El Colegio de México, 2010.

Rosenberg, Nathan, "Adam Smith, consumer tastes, and economic growth", en Journal of Political Economy, 76: 3 (mayo-jun. 1968), pp. 361-374.

SAlazar, Delia y Rosa María Meyer (coords.), Los inmigrantes en el mundo de los negocios, México, Instituto Nacional de Antropología e Historia, 2003.

SÁnchez Parra, Cristina, "Novedad y tradición. Las tiendas por departamentos en la ciudad de México y su influencia en el consumo, 1891-1915”, tesis de doctorado en historia, México, El Colegio de México, 2017.

SCHÁvelzon, Daniel (comp.), La polémica del arte nacional en México, 18501910, México, Fondo de Cultura Económica, 1983.

Simmel, Georg, “The Philosophy of Fashion”, en D. Frisby y M. FeathersTONE, Simmel on Culture, Londres, Sage Publications, 2000, pp. 233-259.

Staples, Anne (coord.), Historia de la vida cotidiana en México, t. IV. Bienes $y$ vivencias. El siglo XIX, México, El Colegio de México, Fondo de Cultura Económica, 2005.

Tenorio, Mauricio, Artilugio de la nación moderna: México en las exposiciones universales, 1880-1930, México, Fondo de Cultura Económica, 1998.

Torre, Judith de la, "La ciudad de México en los albores del siglo xx", en REYEs (coord.), 2006, pp. 11-48.

VALERIo Ulloa, Sergio, "Discursos de las casas comerciales barcelonnettes en Guadalajara (1880-1930)", en Los barcelonnettes en Guadalajara, siglos XIX y $X X$, México, Instituto de Investigaciones Dr. José María Luis Mora, Universidad de Guadalajara, 2015, pp. 299-360.

VAlerio UlloA, Sergio, "Almacenes comerciales franceses en Guadalajara (1850-1930)", en América Latina en la Historia Económica, 23: 1 (ene.-abr. 2016), pp. 68-89.

Williams, Rosalind, Dream Worlds: Mass Consumption in Late NineteenthCentury France, Berkeley, Universidad de California, 1992.

Zola, Émile, El paraíso de las damas, Barcelona, Ediciones Alba, 2009. 